\title{
Study regarding the efficiency of the female players from the BCM Danzio Timișoara basketball team
}

\section{Dan IONESCU ${ }^{1}$}

\begin{abstract}
The game of basketball, as well as other sports activities, tends toward an evolution congruent with the gains of science and contemporary techniques. There are more discussions regarding the activity of sport performance about objectification, optimization, standardization, rationalization, modeling and other notions which had no meaning for the coaches and players during the romantical period of the basketball game. Tracking a team's basketball game means more than just gathering information about the individual or collective style of play. If the statistics about the opponent are made, in general, to exploit their weaknesses, the statistics which are focusing on their own team, help to determine not only if the players are useful or harmful, but it also shows their progress or their setback in a competitive season.

The purpose of this study is to analyze the efficiency of the female players from a basketball team during a competitive season, depending on the season period (first half-second half), the training methods of the coaches, the places where the games are being held (home-away) and the opponent's level.
\end{abstract}

Key words: basketball, objectification, efficiency, BCM Danzio

\section{Rezumat}

Jocul de baschet, la fel ca și alte activități sportive, tinde spre o evoluție în concordanță cu cuceririle științei și tehnicii contemporane. Tot mai mult în activitatea sportivă de performanță se discută despre obiectivizare, optimizare, standardizare, raționalizare, modelare și alte noțiuni care în perioada romantică a jocului de baschet nu aveau nici o semnificație pentru antrenori sau jucători. Urmărirea jocului unei echipe de baschet înseamnă mai mult decât strângerea simplă de informații despre stilul de joc individual sau colectiv. Dacă statisticile despre adversar sunt făcute, în general, pentru a exploata părțile lor slabe, cele asupra propriei echipe ajută atât la determinarea jucătorilor utili sau dăunători echipei, cât și la aflarea jucătorilor care fac progrese sau regrese în timpul unui sezon competițional.

Scopul acestui studiu este de a analiza eficiența jucătoarelor unei echipe de baschet de-a lungul unui sezon competițional, funcție de perioada sezonului (tur - retur), metodele de pregătire ale antrenorilor, locul desfășurării jocurilor (acasă deplasare) și nivelul adversarului.

Cuvinte cheie: baschet, obiectivizare, eficiență, BCM Danzio

\footnotetext{
${ }^{1}$ Lecturer PhD, "Politehnica" University Timișoara, Romania, e-mail: dan.ionescu@upt.ro
} 


\section{Introduction}

The moment a player practices sport not only for his/hers satisfaction, but at one point the purpose of his/hers effort becomes to obtain performance, a range of measures of control must be introduced in order to change your subjective views about the game in objective data. The possibilities of a team should not be assessed by their results, as they are seen by spectators and media, but some indicators have to be analyzed, one of them being the efficiency. One situation is the evaluation of the results when the team lost but the players gave their best and they obeyed every indication of their coach, but the opponent outperformed them, and another one is the situation when the team won but there were several inaccuracies sneaked in the game [1].

\section{Hypothesis and the purpose of the study}

Starting from the hypothesis that the players' efficiency is the main mean of evaluating their evolution during an official game, we have proposed through specific methods, the calculation of this indicator both collectively and individually, to a National League team.

The purpose of this research was to analyze and find out:

- to what extent is the efficiency of the female players influenced by the training methods specific to each coach;

- to what extent is the efficiency of the female players different when playing home rather than away;

- to what extent is the efficiency of the female players dependent on the technical and tactical level of the opponent.

\section{The methods used and the study subjects}

In order to achieve the purpose of the research, the following methods have been used:

- Observation;

It involves the tracking of the phenomenon in question without intervention from the researcher's side in the direction of organizing or progressing the aspect that it examines [2], an example in this sense being the recordkeeping of the game.

- Statistical and mathematical calculation;

- Performance Index Rating - PIR
Performance Index Rating was created in 1991, by the Spanish ACB League, which started using it to determine the league's MVP of the Week and regular season MVP awards [3]. Now, the Performance Index Rating (PIR) is a metric primarily used in European basketball leagues that attempts to give a perspective on a player's total performance. The metric is a simple addition and subtraction of positive and negative game factors [4]. The stat's formula is [5]:

(Points + Rebounds + Assists + Steals + Blocks + Fouls Drawn) - (Missed Field Goals + Missed Free Throws + Turnovers + Shots Rejected + Fouls Committed)

\section{- Efficiency (EFF)}

The efficiency of the players was calculated using the following formula [6]:

$$
\text { EFF }=\frac{\text { Performance Index Rating (PIR) }}{\text { Playing Time }} \times T P B I
$$

where: EFF = efficiency index; TPBI = Time Played Bonus Index (values between 1.1 - 1.7)

The efficiency scale of assessment reflects table I.

Table I. The efficiency scale of assesment and the granting of the evolving mark

\begin{tabular}{|c|c|c|}
\hline $\begin{array}{c}\text { Value intervals of } \\
\text { appreciation of the } \\
\text { EFF }\end{array}$ & Rating & $\begin{array}{c}\text { Efficiency } \\
\%\end{array}$ \\
\hline $0.00-0.19$ & Very weak (VW) & 0 \\
\hline $0.20-0.40$ & Weak (W) & 40 \\
\hline $0.41-0.60$ & Satisfying (S) & 60 \\
\hline $0.61-0.80$ & Good (G) & 80 \\
\hline $0.81-1.00$ & Very Good (VG1) & 100 \\
\hline $1.01-1.20$ & Very Good $\left(\mathrm{VG}_{2}\right)$ & 120 \\
\hline $1.21-1.40$ & Excellent $\left(\mathrm{Ex}_{1}\right)$ & 140 \\
\hline $1.41-1.60$ & Excellent $\left(\mathrm{Ex}_{2}\right)$ & 160 \\
\hline
\end{tabular}

- Arithmetic mean

It represents the resulted mean from the assembly of the each value of the variable related to a total number of cases (the sum of the individual values divided by the number of cases) [7].

- Graphical representation

Graphics are created in order to ease the understanding of the material presented, to illustrate more suggestively analyzed facts [8]. 
In the 2014-2015 season, the Women's National Basketball League (WNBL) has counted 14 teams and the regular season had unfold in the tour retour system, each team playing a total number of 26 games. At the end of the championship, the ranking was as follows: 1. ACS Sepsi SIC Sf. Gheorghe; 2. CSM Târgoviște; 3. Universitatea Goldiș ICIM Arad; 4. CSU Alba Iulia; 5. CSBT Alexandria; 6. BCM Danzio Timişoara; 7. CS Phoenix Galaţi; 8. Olimpia CSU Braşov; 9. CSM Satu Mare; 10. CS Nova Vita Tg. Mureş; 11. Universitatea Cluj Napoca; 12. Universitatea CSM Oradea; 13. SCM CSS Craiova; 14. CS Rapid Bucureşti [9].

The study subjects were the female basketball players from BCM Danzio Timisoara, coaches Ljubomir Kolarevic and Bogdan Bulj.

\section{The results obtained}

Because The Romanian Basketball Federation (FRB) imposes the obligation of carrying out the records during the official games, the index of performance (Performance Index Rating - PIR) of each player was calculated using a computerized statistical program (table II). I have personally calculated the efficiency of each player separately, using the EFF formula. The team's efficiency indicators studied during the 26 official games of the regular season were centralized separately, first half (table III) and second half (table IV), because the two periods correspond with the ones in which two coaches

Table II. Example of statistical sheet used in romanian leagues

\begin{tabular}{|c|c|c|c|c|c|c|c|c|c|c|c|c|c|c|c|c|c|c|c|c|c|c|c|}
\hline \multirow{2}{*}{ No } & \multirow{2}{*}{ Player } & \multirow{2}{*}{ MIN } & \multicolumn{2}{|c|}{$2 P$} & \multicolumn{2}{|c|}{$3 P$} & \multicolumn{2}{|c|}{ FG } & \multicolumn{2}{|c|}{ FT } & \multicolumn{3}{|c|}{ REB } & \multirow{2}{*}{ AS } & \multicolumn{2}{|c|}{ PF } & \multirow{2}{*}{ TO } & \multirow{2}{*}{$\mathbf{S T}$} & \multicolumn{2}{|c|}{ BS } & & 0 & \multirow{2}{*}{ PTS } \\
\hline & & & M/A & $\%$ & M/A & $\%$ & M/A & $\%$ & M/A & $\%$ & $\mathbf{0}$ & D & $\mathbf{T}$ & & CM I & RV & & & FV $A$ & $\mathbf{A G}$ & & $+7-$ & \\
\hline 4 & Denisa Mita & - & & & & & & & & & & & & & & & & & & & & & \\
\hline 5 & Diana Lupu & - & & & & & & & & & & & & & & & & & & & & & \\
\hline 9 & Renata Szmutku & $25: 52$ & $1 / 4$ & $25 \%$ & & & $1 / 4$ & $25 \%$ & & & 3 & 4 & 7 & 2 & 3 & 2 & 3 & 1 & & & 6 & -6 & 2 \\
\hline 10 & ${ }^{*}$ Cristina Zidaru & $33: 51$ & $1 / 4$ & $25 \%$ & $1 / 3$ & $33 \%$ & $2 / 7$ & $29 \%$ & & & & 1 & 1 & 3 & 3 & & 1 & 2 & 2 & & 7 & -6 & 5 \\
\hline 11 & Larisa Neagu & - & & & & & & & & & & & & & & & & & & & & & \\
\hline 15 & Gabriela Magurean & $05: 45$ & $0 / 1$ & & & & $0 / 1$ & & & & & 1 & 1 & & 4 & & & 1 & & & 1 & -4 & \\
\hline 21 & *Briana Claire Wilson & $34: 15$ & $5 / 11$ & $45 \%$ & & & $5 / 11$ & $45 \%$ & $2 / 3$ & $67 \%$ & 9 & 122 & 21 & 5 & 4 & 4 & 3 & & & 1 & 28 & & 12 \\
\hline 22 & Zahra Diana Serrieh & - & & & & & & & & & & & & & & & & & & & & & \\
\hline 32 & *Ivana Grbic & $34: 35$ & $6 / 12$ & $50 \%$ & & & $6 / 12$ & $50 \%$ & $4 / 5$ & $80 \%$ & 3 & 91 & 12 & 2 & 3 & 5 & 7 & 1 & & & 17 & 3 & 16 \\
\hline 33 & *Carlee La Nae Lough & $30: 39$ & $3 / 8$ & $38 \%$ & $1 / 5$ & $20 \%$ & $4 / 13$ & $31 \%$ & & & & & & 3 & 1 & 1 & 4 & 2 & & 1 & 1 & -5 & 9 \\
\hline 55 & *Alexandra Maria Dumitrache & $35: 03$ & $1 / 4$ & $25 \%$ & $5 / 13$ & $38 \%$ & $6 / 17$ & $35 \%$ & $3 / 4$ & $75 \%$ & & & & 3 & 4 & 3 & 6 & 1 & & 1 & 6 & -2 & 20 \\
\hline \multicolumn{2}{|c|}{ Team } & & & & & & & & & & & 3 & 3 & & & & 1 & & & & 2 & & \\
\hline \multicolumn{2}{|c|}{ Totals } & $200: 00$ & $17 / 44$ & $39 \%$ & $7 / 21$ & $33 \%$ & $24 / 65$ & $37 \%$ & $9 / 12$ & $75 \%$ & 15 & 304 & $45 \mid$ & $18 \mid 2$ & 22 & 152 & 25 & 8 & 2 & 3 & 68 & & 64 \\
\hline
\end{tabular}


Table III. The efficiency achived by the female basketabll players from BCM DANZIO in the official matches played in the first half of the competitve season $2014-2015$

\begin{tabular}{|c|c|c|c|c|c|c|c|c|c|c|c|c|c|c|c|}
\hline & Round & I & II & III & IV & V & VI & VII & VIII & IX & $\mathrm{X}$ & $\mathrm{XI}$ & XII & XIII & \multirow{3}{*}{$\begin{array}{l}\text { Efficiency } \\
\text { average }\end{array}$} \\
\hline & $\begin{array}{l}\text { Place } \\
\text { Game }\end{array}$ & \multirow{2}{*}{$\begin{array}{c}\begin{array}{c}\text { Away at } \\
\text { Sf. } \\
\text { Gheorghe } \\
35-65\end{array} \\
\end{array}$} & \multirow{2}{*}{$\begin{array}{l}\text { Away at } \\
\text { Arad } \\
47-61\end{array}$} & \multirow{2}{*}{$\begin{array}{c}\begin{array}{c}\text { Home vs } \\
\text { Alexandria }\end{array} \\
51-70\end{array}$} & \multirow{2}{*}{$\begin{array}{c}\begin{array}{c}\text { Away at } \\
\text { Oradea }\end{array} \\
71-60\end{array}$} & \multirow{2}{*}{$\begin{array}{c}\text { Home vs } \\
\text { Alba }\end{array}$} & \multirow{2}{*}{$\begin{array}{c}\text { Away at } \\
\text { Satu } \\
\text { Mare } \\
74-70\end{array}$} & \multirow{2}{*}{$\begin{array}{c}\text { Home vs } \\
\text { Rapid }\end{array}$} & \multirow{2}{*}{$\begin{array}{c}\text { Home vs } \\
\text { Tg. Mures } \\
86-70\end{array}$} & \multirow{2}{*}{$\begin{array}{l}\text { Away at } \\
\text { Craiova }\end{array}$} & \multirow{2}{*}{$\begin{array}{c}\text { Home vs } \\
\text { Galati }\end{array}$} & \multirow{2}{*}{$\begin{array}{c}\text { Away at } \\
\text { Brasov }\end{array}$} & \multirow{2}{*}{$\begin{array}{l}\text { Home vs } \\
\text { Cluj N. } \\
74-65\end{array}$} & \multirow{2}{*}{$\begin{array}{c}\text { Away at } \\
\text { Targoviste } \\
39-80 \\
\end{array}$} & \\
\hline & Result & & & & & & & & & & & & & & \\
\hline \multirow{14}{*}{ 离 } & Pesovic & 0,29 & 0,78 & 0,40 & 0,87 & 1,36 & 1,44 & 1,78 & 1,44 & 1,18 & 1,06 & 1,02 & 0,08 & 0 & 0,90 \\
\hline & Geleriu & 0 & 0 & $\begin{array}{c}\text { DID NOT } \\
\text { PLAY }\end{array}$ & 0 & $\begin{array}{l}\text { DID NOT } \\
\text { PLAY }\end{array}$ & $\begin{array}{c}\text { DID NOT } \\
\text { PLAY }\end{array}$ & 0 & 0 & 0 & 1 & $\begin{array}{l}\text { DID NOT } \\
\text { PLAY }\end{array}$ & $\begin{array}{l}\text { DID NOT } \\
\text { PLAY }\end{array}$ & 0 & 0,125 \\
\hline & Erak & 0,66 & 0,12 & 0,20 & 0,77 & 0,77 & 0,55 & 1,20 & 0,70 & 1,01 & 1,11 & 0,67 & 0,46 & 0,32 & 0,65 \\
\hline & Krnjetin & 0 & 0,55 & 0.55 & 0,13 & 0,34 & 0,80 & 1,08 & 0.82 & 0,66 & 0,76 & 0 & 1,02 & 0,34 & 0,54 \\
\hline & Moraru & 0 & 0,29 & 0,12 & 0,52 & 0 & 0 & 0,70 & 0,51 & 1 & 0 & 0,26 & 0 & 0,19 & 0,27 \\
\hline & Zidaru & 0 & 0 & 0 & $\begin{array}{l}\text { DID NOT } \\
\text { PLAY }\end{array}$ & 0,33 & 0 & 0 & 0,16 & 0 & 0,27 & 0 & 0 & 0,48 & 0,10 \\
\hline & Karakasevic & 0 & 0 & 0,44 & 0,72 & 0,50 & 0,65 & 1,33 & 0.97 & 1,90 & 0,58 & 1,20 & 1,78 & 0.25 & 0,79 \\
\hline & Jovovic & 0,10 & $\begin{array}{c}\text { DID NOT } \\
\text { PLAY }\end{array}$ & $\begin{array}{l}\text { DID NOT } \\
\text { PLAY }\end{array}$ & $\begin{array}{c}\text { DID NOT } \\
\text { PLAY }\end{array}$ & $\begin{array}{c}\text { DID NOT } \\
\text { PLAY }\end{array}$ & $\begin{array}{c}\text { DID NOT } \\
\text { PLAY }\end{array}$ & $\begin{array}{c}\text { DID NOT } \\
\text { PLAY }\end{array}$ & $\begin{array}{l}\text { DID NOT } \\
\text { PLAY }\end{array}$ & $\begin{array}{c}\text { DID NOT } \\
\text { PLAY }\end{array}$ & $\begin{array}{c}\text { DID NOT } \\
\text { PLAY }\end{array}$ & $\begin{array}{c}\text { DID NOT } \\
\text { PLAY }\end{array}$ & 0 & 0 & 0,03 \\
\hline & Stefan & $\begin{array}{c}\text { DID NOT } \\
\text { PLAY }\end{array}$ & I & 1 & 0,12 & 0 & 0 & 0.07 & \multicolumn{6}{|c|}{ TRANSFERRED } & 0,23 \\
\hline & Steiner & $\begin{array}{l}\text { DID NOT } \\
\text { PLAY }\end{array}$ & $\begin{array}{l}\text { DID NOT } \\
\text { PLAY }\end{array}$ & $\begin{array}{l}\text { DID NOT } \\
\text { PLAY }\end{array}$ & 0 & $\begin{array}{c}\text { DID NOT } \\
\text { PLAY }\end{array}$ & $\begin{array}{c}\text { DID NOT } \\
\text { PLAY }\end{array}$ & $\begin{array}{l}\text { DID NOT } \\
\text { PLAY }\end{array}$ & 0 & \multicolumn{5}{|c|}{ TRANSFERRED } & 0 \\
\hline & Stoiedin & DNP & 0,22 & 0,28 & 0,24 & 0,40 & 0.51 & 0,88 & 0,33 & 0,80 & 1,13 & 0,60 & 0,38 & 0,32 & 0,50 \\
\hline & Ghizila & $\begin{array}{l}\text { DID NOT } \\
\text { PLAY }\end{array}$ & $\begin{array}{l}\text { DID NOT } \\
\text { PLAY }\end{array}$ & $\begin{array}{l}\text { DID NOT } \\
\text { PLAY }\end{array}$ & 1 & $\begin{array}{c}\text { DID NOT } \\
\text { PLAY }\end{array}$ & $\begin{array}{c}\text { DID NOT } \\
\text { PLAY }\end{array}$ & $\begin{array}{c}\text { DID NOT } \\
\text { PLAY }\end{array}$ & \multicolumn{6}{|c|}{ TRANSFERRED } & 1 \\
\hline & Dumitrache & 0,09 & 0 & 0,34 & 0,39 & 0,08 & 0,18 & 0,37 & 0.53 & 0,72 & 0,35 & 0,40 & 0,68 & 0 & 0,31 \\
\hline & Zahra & $\begin{array}{c}\text { DID NOT } \\
\text { PLAY }\end{array}$ & $\begin{array}{c}\text { DID NOT } \\
\text { PLAY }\end{array}$ & $\begin{array}{l}\text { DID NOT } \\
\text { PLAY }\end{array}$ & $\begin{array}{c}\text { DID NOT } \\
\text { PLAY }\end{array}$ & $\begin{array}{c}\text { DID NOT } \\
\text { PLAY }\end{array}$ & $\begin{array}{c}\text { DID NOT } \\
\text { PLAY }\end{array}$ & $\begin{array}{c}\text { DID NOT } \\
\text { PLAY }\end{array}$ & 0 & $\begin{array}{l}\text { DID NOT } \\
\text { PLAY }\end{array}$ & 0 & $\begin{array}{l}\text { DID NOT } \\
\text { PLAY }\end{array}$ & $\begin{array}{l}\text { DID NOT } \\
\text { PLAY }\end{array}$ & $\begin{array}{l}\text { DID NOT } \\
\text { PLAY }\end{array}$ & 0 \\
\hline \multicolumn{2}{|c|}{$\operatorname{Mean}(\bar{X})$} & 0,12 & 0,21 & 0,37 & 0,43 & 0,42 & 0,45 & 0,74 & 0,49 & 0,80 & 0,62 & 0,51 & 0.48 & 0,19 & 0,44 \\
\hline
\end{tabular}

Table IV. The efficiency achived by the female players from BCM DANZIO Timişoara in the official matches played in the second half of the competitive season $2014-2015$

\begin{tabular}{|c|c|c|c|c|c|c|c|c|c|c|c|c|c|c|c|}
\hline \multirow{3}{*}{\multicolumn{2}{|c|}{$\begin{array}{c}\text { Round } \\
\text { Place } \\
\text { Game } \\
\text { Result }\end{array}$}} & XIV & $\mathrm{XV}$ & XVI & XVII & XVIII & XIX & $\mathrm{XX}$ & XXI & XXII & XXIII & XXIV & $\mathrm{XXV}$ & XXVI & \multirow{3}{*}{$\begin{array}{l}\text { Efficiency } \\
\text { average }\end{array}$} \\
\hline & & $\begin{array}{l}\text { Home vs } \\
\text { Sf. } \\
\text { Gheorghe }\end{array}$ & $\begin{array}{c}\text { Home vs } \\
\text { Arad }\end{array}$ & $\begin{array}{c}\text { Away at } \\
\text { Alexandria }\end{array}$ & $\begin{array}{l}\text { Home vs } \\
\text { Oradea }\end{array}$ & $\begin{array}{l}\text { Away at } \\
\text { Alba }\end{array}$ & $\begin{array}{l}\text { Home vs } \\
\text { Satu } \\
\text { Mare }\end{array}$ & $\begin{array}{l}\text { Away at } \\
\text { Rapid }\end{array}$ & $\begin{array}{l}\text { Away at } \\
\text { Tg. Mures }\end{array}$ & $\begin{array}{l}\text { Home vs } \\
\text { Craiova }\end{array}$ & $\begin{array}{c}\text { Away at } \\
\text { Galati }\end{array}$ & $\begin{array}{l}\text { Home vs } \\
\text { Brasov }\end{array}$ & $\begin{array}{l}\text { Away at } \\
\text { Cluj N. }\end{array}$ & $\begin{array}{l}\text { Home vs } \\
\text { Targoviste }\end{array}$ & \\
\hline & & $43-73$ & $65-82$ & $73-61$ & $81-37$ & $94-58$ & $84-56$ & $95-65$ & $83-55$ & $96-55$ & $67-51$ & $78-70$ & $91-49$ & $42-68$ & \\
\hline \multirow{12}{*}{$\stackrel{\grave{\Xi}}{\stackrel{\Xi}{a}}$} & Pesovic & 0,32 & 0,44 & 0,89 & 1,92 & 0 & 1,20 & 1,39 & 1,60 & 0,80 & 0,82 & 1,06 & 0,72 & $\begin{array}{l}\text { DID NOT } \\
\text { PLAY }\end{array}$ & 0,93 \\
\hline & Geleriu & $\begin{array}{l}\text { DID NOT } \\
\text { PLAY }\end{array}$ & $\begin{array}{l}\text { DID NOT } \\
\text { PLAY }\end{array}$ & $\begin{array}{l}\text { DID NOT } \\
\text { PLAY }\end{array}$ & 0 & $\begin{array}{l}\text { DID NOT } \\
\text { PLAY }\end{array}$ & $\begin{array}{l}\text { DID NOT } \\
\text { PLAY }\end{array}$ & 0 & 0 & 0.76 & 0 & $\begin{array}{l}\text { DID NOT } \\
\text { PLAY }\end{array}$ & 0 & 0 & 0,10 \\
\hline & Erak & 0,18 & 0,28 & 0,94 & 1,13 & 0,09 & 0,86 & \multicolumn{7}{|c|}{ TRANSFERRED } & 0,58 \\
\hline & Krnjetin & 0 & 0,21 & 0 & 0,15 & 0 & 0,56 & 1,08 & 0,44 & $\begin{array}{l}\text { DID NOT } \\
\text { PLAY }\end{array}$ & 0,70 & 0,53 & $\begin{array}{l}\text { DID NOT } \\
\text { PLAY }\end{array}$ & $\begin{array}{l}\text { DID NOT } \\
\text { PLAY }\end{array}$ & 0,36 \\
\hline & Moraru & 0,30 & 0,11 & 0,11 & 0 & 0 & 0,75 & \multicolumn{7}{|c|}{ TRANSFERRED } & 0,21 \\
\hline & Zidaru & 0 & 0 & $\begin{array}{l}\text { DID NOT } \\
\text { PLAY }\end{array}$ & 0 & 0,75 & $\begin{array}{l}\text { DID NOT } \\
\text { PLAY }\end{array}$ & 0,60 & 0 & 0 & 0 & $\begin{array}{l}\text { DID NOT } \\
\text { PLAY }\end{array}$ & 0,48 & 0,10 & 0,19 \\
\hline & Karakasevic & 0,61 & 0,68 & 1,13 & 1,37 & 1,40 & $\begin{array}{l}\text { DID NOT } \\
\text { PLAY }\end{array}$ & 1,27 & 1,44 & 1,65 & 1,29 & 0,95 & 2,21 & 0,72 & 1,22 \\
\hline & Jovovic & 0,06 & 0,65 & 0 & 0,22 & 0,79 & 0,87 & 0,36 & 0,33 & 0,87 & 0,62 & 0,40 & 0,61 & 0,25 & 0,46 \\
\hline & Stoiedin & 0,46 & 0,33 & 0 & 0,70 & 0.07 & 0,67 & 0,79 & 0,89 & 1,17 & 0,30 & 0,93 & $\begin{array}{l}\text { DID NOT } \\
\text { PLAY }\end{array}$ & 0 & 0,52 \\
\hline & Dumitrache & 0,08 & $\begin{array}{l}\text { DID NOT } \\
\text { PLAY }\end{array}$ & 0,32 & 0 & 0,34 & 0,30 & 0,62 & 0,46 & 0,36 & 0,08 & 0,30 & 0,68 & 0 & 0,29 \\
\hline & Zahra & $\begin{array}{l}\text { DID NOT } \\
\text { PLAY }\end{array}$ & $\begin{array}{l}\text { DID NOT } \\
\text { PLAY }\end{array}$ & $\begin{array}{l}\text { DID NOT } \\
\text { PLAY }\end{array}$ & 1 & $\begin{array}{l}\text { DID NOT } \\
\text { PLAY }\end{array}$ & $\begin{array}{l}\text { DID NOT } \\
\text { PLAY }\end{array}$ & $\begin{array}{l}\text { DID NOT } \\
\text { PLAY }\end{array}$ & $\begin{array}{l}\text { DID NOT } \\
\text { PLAY }\end{array}$ & 0 & $\begin{array}{l}\text { DID NOT } \\
\text { PLAY }\end{array}$ & $\begin{array}{l}\text { DID NOT } \\
\text { PLAY }\end{array}$ & $\begin{array}{l}\text { DID NOT } \\
\text { PLAY }\end{array}$ & $\begin{array}{l}\text { DID NOT } \\
\text { PLAY }\end{array}$ & 0,50 \\
\hline & Maximovic & 0,16 & 0,76 & 0,55 & 1,16 & 0,85 & 1,13 & 1,30 & 1,17 & 1,33 & 0.60 & 0,82 & 1,34 & 0,59 & 0,90 \\
\hline \multicolumn{2}{|c|}{$\operatorname{Mean}(\bar{X})$} & 0,21 & 0,38 & 0,43 & 0,63 & 0,42 & 0,79 & 0,82 & 0,70 & 0.77 & 0,49 & 0,71 & 0,86 & 0,23 & 0,57 \\
\hline
\end{tabular}

(Ljubomir Kolarevic - first half, Bogdan Bulj second half) have succeeded at the team's helm.

The players' behavior in terms of competition revealed an increase in their efficiency and implicitly the team's average in the second part of the regular season (Figure 1). Thus, if in the first part of the season the efficiency average of the team was 0.44 , in the second part of the season has reached 0.57. In addition to other factors, this difference can be put on the behalf of various methods and means of training used by coaches in charge of the team during those periods. 


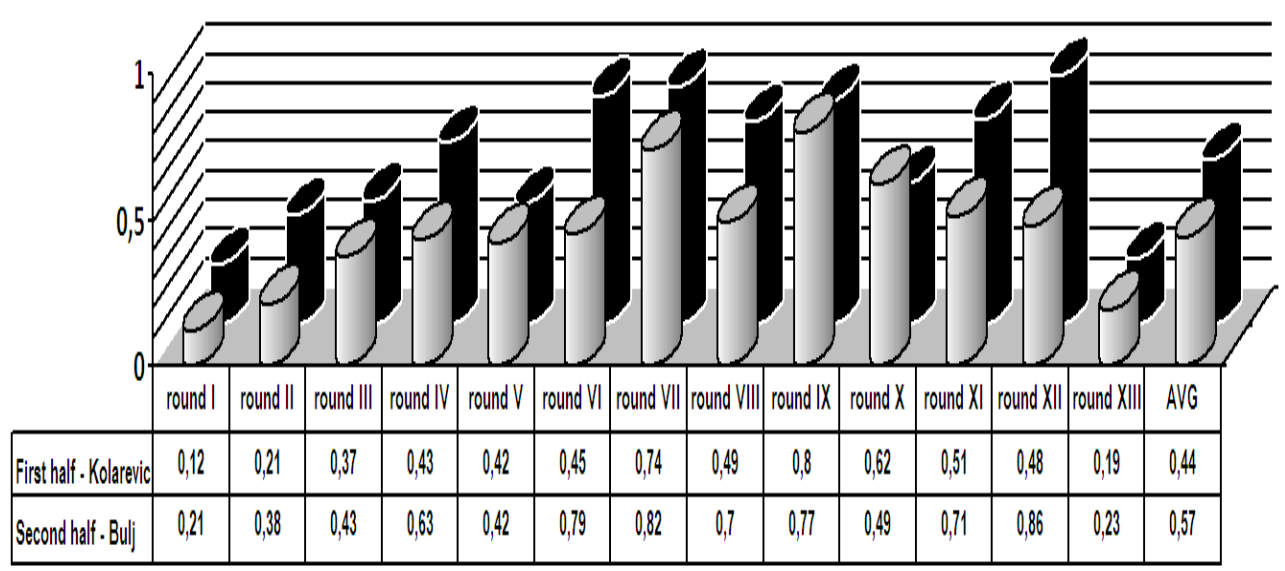

Figure 1. The average efficiency of the team BCM DANZIO Timişoara in the matches played the fist half and second half of the competitive season 2014-2015

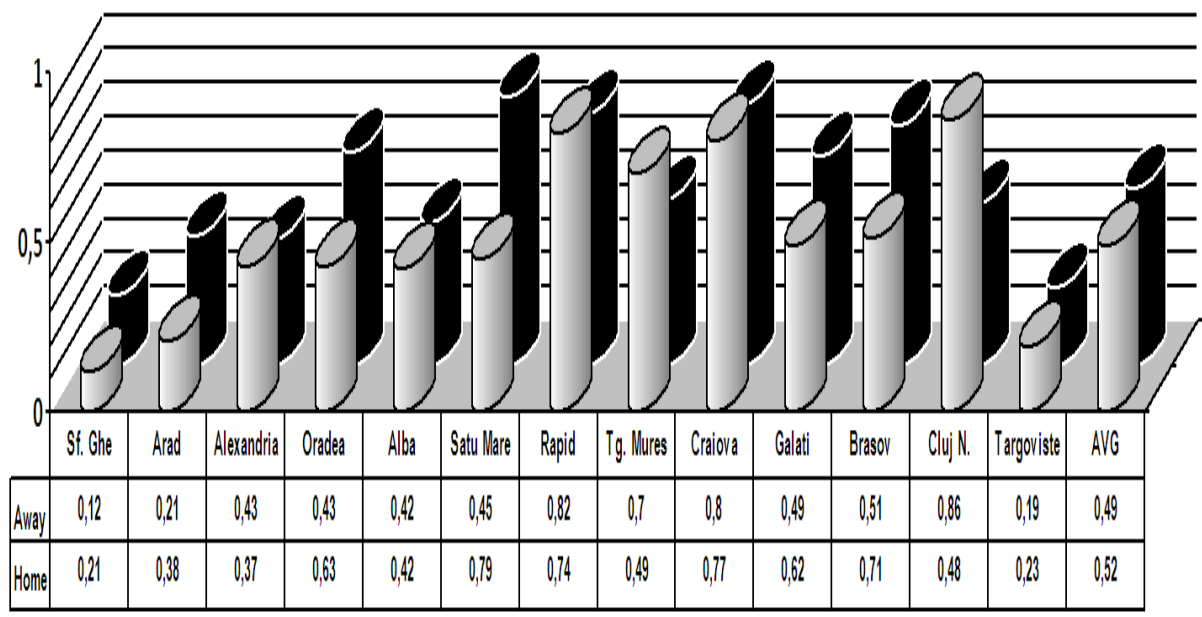

Figure 2. The average efficiency of the team BCM DANZIO Timişoara in the matches played home and the ones played away

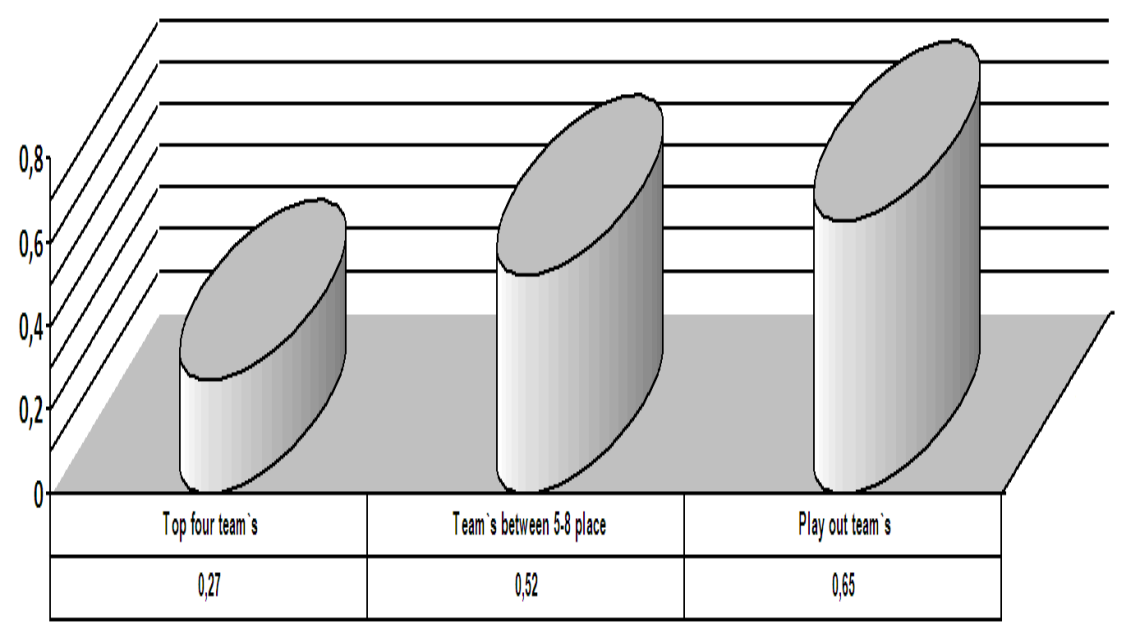

Figure 3. The average efficiency of the team BCM DANZIO Timişoara in the matches played against the opponents of different values 
The comparison between the team's efficiency at away matches (0.49) and those played home (0.52), shows that they are really close to each other (Figure 2), which denotes that not the opponent's court or the hostile public are the reasons for losing matches, once again confirming that the failures are motivated by other factors and require thorough study of each game individually, but in the same manner require the analysis of the performance of the opponent team, which can be determined in order to establish the causes of failures.

It also results from the statistical analysis the fact that once the opponent's values increase, the efficiency of the studied team decreases (Figure 3). Thus, the efficiency of the teams ranked outside the play-off was 0.65 (Good), against the teams situated on the places 5-8 where the efficiency was 0.52 (Satisfying), whereas the efficiency of the Top 4 ranked teams has decreased to 0.27 (Weak).

After all the conducted games in The National Women's Basketball League, the Performance Index Rating (PIR) of the team BCM Danzio Timisoara was 2451, respectively an average of 79.06 per game. Compared to the other participating teams in The National League (table V), the average of the performance index of the studied team was ranked on the $6^{\text {th }}$ place (exactly the place from the leaderboard at the end of the regular season).

Regarding the individual efficiency of the players who have evolved in at least $25 \%$ of the analyzed matches, the statistical calculation shows that only 3 players have had their efficiency evaluated as very good (Karakasevic 1.0; Pesovic 0.91; Maksimovic 0.90), and just a single female player had the efficiency evaluated as good (Erak 0.63). The remaining female players had the efficiency evaluated as satisfying, weak and very weak (Figure 4). As a result of these individual developments, the observed team was ranked at the end of the regular season on the sixth place.

\section{Conclusions}

As a result of the experiment conducted on the team BCM Danzio Timisoara, to illustrate the efficiency of the study, the following conclusions can be drawn:

- Whoever the coach in charge of the studied team and the place where the official games were held (home-away), the average efficiency was rated as satisfying;

- The place obtained by the studied team at the end of the regular season, fully reflects the value of the players and it is in accordance with their efficiency throughout all analyzed matches;

- As the opponent's value increase, the team's average efficiency decreases;

- The average efficiency is higher in the matches played home rather than in the ones away;

- The difference between the extreme performances (amplitude) [10] has values between 0.21 and 0.86 in the matches played away and between 0.21 and 0.79 in the matches played home. This fact puts in front of the coaches the issue of emphasizing factors which determine the efficiency, in order to minimize the fluctuation from one stage to another;

- The data collected through the statistical analysis can put at the coaches' disposal a series of useful information which can be helpful in correcting the future training methods. 
Table V. Number of the games, the Performance Index Rating and average of PIR registered by National Women Basketball League - 2014/2015 season

\begin{tabular}{|c|l|c|c|c}
\hline No. & \multicolumn{1}{c|}{ Team } & Total games & $\begin{array}{c}\text { Performance Index Rating } \\
\text { (PIR) }\end{array}$ & Average (PIR) \\
\hline 1. & ACS Sepsi SIC & 35 & 3508 & 100.23 \\
\hline 2. & CS Municipal Targoviste & 35 & 3447 & 98.49 \\
\hline 3. & Univ Goldis ICIM Arad & 32 & 3085 & 96.41 \\
\hline 4. & CSU Alba Iulia & 32 & 2836 & 88.63 \\
\hline 5. & Olimpia CSU Brasov & 30 & 2434 & 81.13 \\
\hline 6. & BCM Danzio Timisoara & 31 & 2451 & 78.06 \\
\hline 7. & CSBT Alexandria & 31 & 2442 & 72.55 \\
\hline 8. & CS Phoenix Galati & 31 & 2249 & 71.17 \\
\hline 9. & CS Municipal Satu Mare & 30 & 2135 & 66.37 \\
\hline 10. & CS Nova Vita & 30 & 1991 & 52.57 \\
\hline 11. & Universitatea Cluj-Napoca & 30 & 1577 & 43.61 \\
\hline 12. & Universitatea CSM Oradea & 31 & 1352 & 40.84 \\
\hline 13. & CS Rapid Bucuresti & 31 & 1266 & 40.29 \\
\hline 14. & SCM CSS Craiova & 31 & 1249 & \\
\hline
\end{tabular}

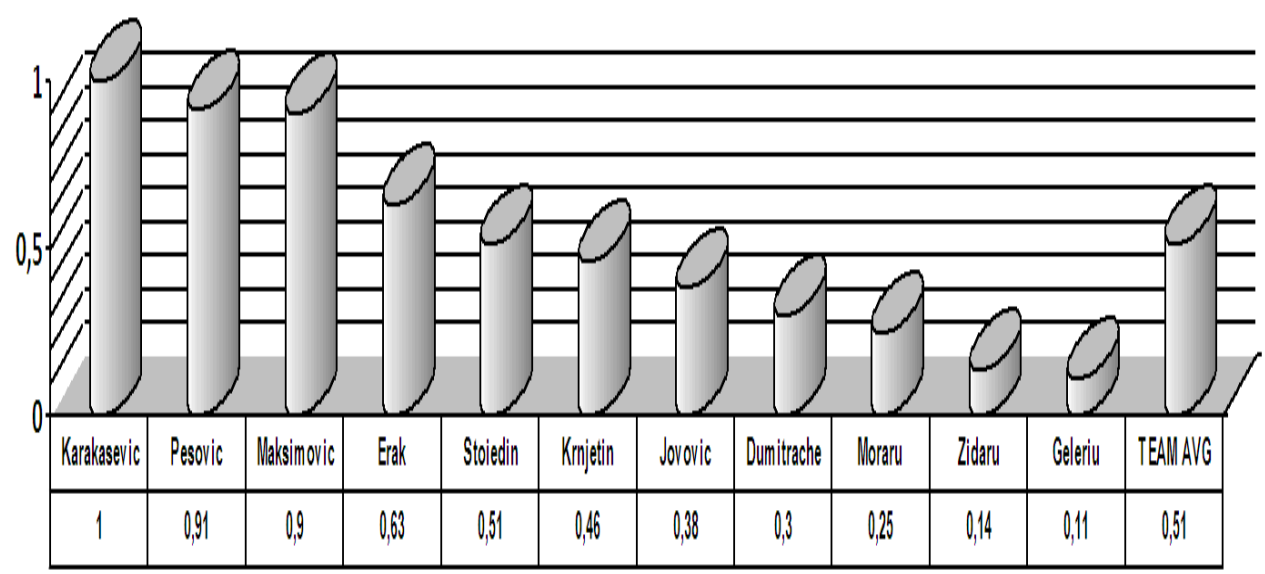

Figure 4. The average efficiency of the female players from BCM DANZIO Timişoara in the matches played in the competitive season 2014-2015 


\section{References}

1. Bachner L., (1998). Obiectivizarea jocului de baschet, Editura Mirton, Timișoara.

2. Hanțiu I., (2013). Educație fizică și sport. Teorie și metodică (Note de curs), Oradea.

3. https://en.wikipedia.org/wiki/Performance_Index_Rating, accessed at 04.03.2016.

4. https://captaincalculator.com/sports/basketball/performa nce-index-rating-calculator/, accessed at 28.03.2016.

5. Novšak Š.,(2014). Statistical analysis of the PIR basketball player performance index, EngD thesis, University of Ljubljana.
6. Colibaba-Evulet D., Bota I., (1998). Jocuri sportive, Teorie si metodică, Editura Aldin, Bucuresti.

7. Dragnea A., (1984). Măsurarea și evaluarea în educație fizică și sport, Editura Sport-Turism, București.

8. Popa Gh., (1999). Metodologia cercetării științifice în domeniul educației fizice și sportului, Editura Orizonturi Universitare, Timișoara.

9. http://www.frbaschet.ro/campionatfeminin/?season_id=8 9981\#mbt:17-300\$f\&group=158137, accessed at 07.04.2016.

10. Clocotici V., Stan A., (2001). Statistică aplicată în psihologie, Editura Polirom, Iași. 